\title{
Molecular and immunological evaluation of the expression of cancer/testis gene products in human colorectal cancer
}

\author{
Pedro M. S. Alves • Nicole Lévy • Hanifa Bouzourene • Sébastien Viatte • \\ Gabriel Bricard • Maha Ayyoub • Henri Vuilleumier • Jean-Claude R. Givel • \\ Nermin Halkic • Daniel E. Speiser • Pedro Romero • Frédéric Lévy
}

Received: 16 June 2006 / Accepted: 8 August 2006 / Published online: 8 September 2006

(C) Springer-Verlag 2006

\begin{abstract}
Tumor-specific gene products, such as cancer/testis (CT) antigens, constitute promising targets for the development of $\mathrm{T}$ cell vaccines. Whereas $\mathrm{CT}$ antigens are frequently expressed in melanoma, their expression in colorectal cancers (CRC) remains poorly characterized. Here, we have studied the expression of the CT antigens MAGE-A3, MAGE-A4, MAGE-A10, NY-ESO-1 and SSX2 in CRC because of the presence of well-described HLA-A2-restricted epitopes in their sequences. Our analyses of 41 primary CRC and 14
\end{abstract}

P. M. S. Alves · S. Viatte · P. Romero · F. Lévy $(\varangle)$

NCCR, Molecular Oncology, ISREC, Ch. des Boveresses

155, 1066 Epalinges, Switzerland

e-mail: frederic.levy@isrec.unil.ch

P. M. S. Alves $\cdot$ S. Viatte $\cdot$ F. Lévy

Ludwig Institute for Cancer Research, Lausanne Branch,

University of Lausanne, Ch. des Boveresses 155,

1066 Epalinges, Switzerland

P. M. S. Alves · G. Bricard - M. Ayyoub - D. E. Speiser ·

P. Romero

Division of Clinical Onco-Immunology, Ludwig Institute for Cancer Research, Lausanne Branch, University Hospital (CHUV), 1005 Lausanne, Switzerland

N. Lévy

Department of Biochemistry, University of Lausanne,

Ch. des Boveresses 155, 1066 Epalinges, Switzerland

\section{H. Bouzourene}

Institute of Pathology, University of Lausanne,

rue du Bugnon 25, 1011 Lausanne, Switzerland

H. Vuilleumier · J.-C. R. Givel $\cdot$ N. Halkic

Department of Visceral Surgery, University Hospital

(CHUV), 1011 Lausanne, Switzerland metastatic liver lesions confirmed the low frequency of expression of these CT antigens. No increased expression frequencies were observed in metastatic tumors compared to primary tumors. Histological analyses of CRC samples revealed heterogeneous expression of individual CT antigens. Finally, evidence of a naturally acquired $\mathrm{CT}$ antigen-specific $\mathrm{CD}^{+} \mathrm{T}$ cell response could be demonstrated. These results show that the expression of CT antigens in a subset of CRC patients induces readily detectable $\mathrm{T}$ cell responses.

Keywords Colorectal cancer - Cancer-testis antigen · $\mathrm{T}$ cell response

$\begin{array}{ll}\text { Abbreviations } \\ \text { CT } & \text { Cancer/testis } \\ \text { CRC } & \text { Colorectal cancer } \\ \text { PBMC } & \text { Peripheral blood mononuclear cell } \\ \text { HLA-A2 } & \text { HLA-A*0201 }\end{array}$

\section{Introduction}

Colon cancer is one of the most frequent cancers in affluent countries. Its prognosis remains poor, with 5year survival rates approximating $40 \%$ [1], because the diagnosis is frequently made at an advanced stage of the disease. Although $80 \%$ of colorectal cancer (CRC) patients undergo a complete macroscopic removal of their malignant lesions by surgical resection, a significant proportion of them recur, usually as a result of already disseminated micrometastases at the time of surgery. Among the new approaches targeting these disseminated tumor cells, the use of tumor-specific cytolytic T lymphocytes (CTL) are of 
particular interest. In that context, the presence of tumor-infiltrating $\mathrm{T}$ lymphocytes has been found to be associated with prolonged survival [2-4]. Even if the specificities of these $\mathrm{T}$ lymphocytes have not yet been elucidated, in vivo stimulation of CRC-specific $\mathrm{T}$ lymphocytes could be envisaged as adjuvant therapy to tumor resection.

Over the last 15 years, many tumor-associated antigens recognized specifically by $\mathrm{CD} 8^{+} \mathrm{T}$ lymphocytes have been identified and characterized. These antigens are commonly classified into four categories: cancer/testis (CT) antigens (aka cancer/germline or shared tumor-specific antigens), differentiation antigens, overexpressed antigens and antigens resulting from patient-specific point mutations. In CRC, CT antigens are particularly interesting targets because they are predicted to be expressed specifically by the tumor cells and not by the adjacent normal epithelial cells. Such specificity is not expected for antigens of the second and third category and may therefore reduce their usefulness in the immunotherapeutic treatment of CRC because of the side effects associated with the potential destruction of normal colon epithelia. Unfortunately, contrary to metastatic melanoma in which CT genes are expressed at frequencies ranging from 20 to $70 \%, \mathrm{CRC}$ is generally considered as a poor $\mathrm{CT}$ antigen expresser since less than $10 \%$ of all analyzed CT genes are expressed at frequencies exceeding $20 \%$ [5]. Despite the rare expression of most CT genes, it remains unclear if the expression of one or the other $\mathrm{CT}$ antigen can elicit spontaneous $\mathrm{T}$ cell responses in CRC patients, as is the case for melanoma patients [6-9].

In this work, we monitored the expression of $\mathrm{CT}$ antigens in primary lesions and liver metastases of 51 CRC patients. We focused our analysis on CT antigens for which HLA-A2-restricted peptides had been previously identified. Expression was analyzed by semi-quantitative PCR and, in selected patients, by immunohistochemical staining of paraffin-embedded tumor sections. Our results indicate that CT antigens are rarely expressed in primary and metastatic colorectal tumors. However, in those patients that showed $\mathrm{CT}$ antigen expression in the primary CRC, the expression was maintained in the metastases. Finally, two patients bearing NY-ESO-1- and MAGE-A3positive tumors (detected by RT-PCR and immunohistochemistry), respectively, were found to have detectable frequencies of circulating $\mathrm{CD}^{+} \mathrm{T}$ lymphocytes reactive against these antigens. Taken together, our results indicate that spontaneous $\mathrm{T}$ cell responses can be elicited by the expression of $\mathrm{CT}$ antigens in CRC lesions.

\section{Materials and methods}

\section{Patients}

Peripheral blood mononuclear cell (PBMC) and tumor samples of CRC patients were obtained after informed consent. The study protocol was approved by the Ludwig Institute for Cancer Research ethical review committee, as well as by the medical and ethical committees of the University Hospital (Lausanne, Switzerland). The patients' HLA haplotype was determined by serological typing. All patients were operated according to standard procedures and none of them was treated with preoperative neoadjuvant therapy. There were 4 stage I (T1-T2, N0, M0), 9 stage II (T3-T4, N0, M0), 4 stage III (any T, N1, M0) and 37 stage IV (any T, any N, M1) patients according to the TNM classification, sixth edition (2002).

\section{Tissue preparation}

Tissue samples from normal colonic mucosa, normal liver, colon cancer and metastatic colon cancer were obtained at the time of surgical resection. Tissue fragments were cut into small fragments and immediately frozen in liquid nitrogen. Samples were stored at $-80^{\circ} \mathrm{C}$ until the time of mRNA extraction. In parallel, tissue samples were also embedded in paraffin and used for pathological analysis (TNM, sixth edition 2002) and tumor staging.

\section{Isolation of mRNA and synthesis of cDNA}

Frozen fragments were processed using Qiagen RNAeasy MiniKit (Qiagen, Hilden, Germany). In brief, frozen material was weighed and mechanically dissociated by Polytron (Kinematica AG, Newark, NY, USA) in RLT buffer following the manufacturer's instructions. The samples were then treated with DNAse I (Qiagen) to remove genomic DNA. Purified mRNA was quantified by spectrophotometry and stored at $-80^{\circ} \mathrm{C}$. mRNA was reverse-transcribed to cDNA using Qiagen RT-PCR Kit (Qiagen), starting from $4 \mu \mathrm{g}$ mRNA for each sample.

\section{Semi-quantitative PCR}

The sequences of primer pairs used to amplify each CT antigen have been described previously [10-12]. Intersample mRNA content was evaluated by quantitative real-time PCR on the house-keeping gene $\beta$-actin (primers: 5'-GGCATCGTGATGGACTCCG -3'; 5'GCTGGAAGGTGGACAGCGA-3') associated with 
SYBR Green I dye (Roche Applied Science, Rotkreuz, Switzerland). Reactions were performed in a LightCycler 1.5 Instrument following manufacturer's instructions (Roche Applied Science). Relative abundance of $\beta$-actin mRNA did not vary by more than threefold among all samples tested (data not shown). CT genes were analyzed by semi-quantitative PCR on serial fivefold dilutions of cDNA. HotStarTaq DNA Polymerase (Qiagen) was used in all reactions following the manufacturer's instructions, with the exception of NY-ESO-1, which was performed using Taq DNA polymerase and the addition of $\mathrm{Q}$ solution (Qiagen). Thermocycling conditions were the following: MAGE-A3 (annealing temp $66^{\circ} \mathrm{C}, 31$ cycles); MAGEA4 (annealing temp $68^{\circ} \mathrm{C}, 33$ cycles); MAGE-A10 (annealing temp $55^{\circ} \mathrm{C}, 39$ cycles); NY-ESO-1 (annealing temp $60^{\circ} \mathrm{C}, 37$ cycles); SSX2 (annealing temp $62^{\circ} \mathrm{C}$, 40 cycles). All reactions were performed in a T3 thermocycler (Biometra, Göttingen, Germany). Expression was scored positive when a band was visible on agarose gel stained with ethidium bromide at any of the three dilutions. Absence of detectable band was scored as negative.

\section{Immunohistochemistry}

Tumor samples were fixed in $4 \%$ buffered formalin, embedded in paraffin and stained with hematoxylin and eosin. Additional sections were studied by immunohistochemistry with two pan-MAGE-A monoclonal antibodies (clones 57B and 6C1) and the monoclonal anti-NY-ESO-1 antibody (clone D8.38) [13, 14]. Paraffin-embedded slides of testicular seminoma were used as positive controls. Immunohistochemistry slides were developed using Ultrateck-Peroxidase kit (Beckman Coulter, Fullerton, USA).

Isolation and expansion of peripheral blood lymphocytes

Blood samples from patients LAU846 and LAU911 were obtained before surgery. Ficoll-Paque centrifuged PBMC were cryopreserved in RPMI 1640 (Invitrogen, Basel, Switzerland) supplemented with $40 \%$ FCS, and 10\% DMSO. In CTL induction assays, PBMC were thawed and plated in 96 U-bottom plates at $2 \times 10^{5}$ cells/well in the presence of $10 \mu \mathrm{M}$ peptide and $1 \mu \mathrm{g} / \mathrm{ml} \beta 2$-microglobulin (Sigma, Oakville, Canada), in RPMI 1640 supplemented with $8 \%$ pooled human serum, Penicillin/Streptomycin, HEPES and 2mercaptoethanol (culture media), as described elsewhere [15]. Seventy-two hours later, 1,000 IU/ml IL-2 was added to cultures and the culture media was replaced every second day until the day of functional analysis (day 10).

\section{Tetramer analysis}

Cytolytic T lymphocytes generated from PBMC were stained with Phycoerythrin-labeled HLA-A2/peptide tetramers. Cells $\left(10^{6}\right)$ were incubated with tetramers $(10 \mu \mathrm{g} / \mathrm{ml}, 60 \mathrm{~min}$ at room temperature $)$ and then with anti-human $\mathrm{CD} 8 \alpha \mathrm{mAb}\left(30 \mathrm{~min}, 4^{\circ} \mathrm{C}\right)$. Dead cells were electronically excluded by propidium-iodide staining. $\mathrm{CD}^{+} \mathrm{T}$ cells $\left(5 \times 10^{5}\right.$ cells per sample $)$ were analyzed by flow cytometry on a FACScan machine using CellQuest software (BD Biosciences, San Jose, CA).

\section{IFN- $\gamma$ ELISPOT assay}

Human IFN- $\gamma$ ELISPOT PVDF-Enzymatic kit (Diaclone, Besançon, France) was used according to the manufacturer's instructions. Human IFN- $\gamma$-specific capture $\mathrm{mAb}$ were adsorbed on MultiScreen-HA Filter 96 well Plates (Millipore, Billerica, MA, USA) for $16 \mathrm{~h}$ at $4{ }^{\circ} \mathrm{C}$ and blocked with RPMI supplemented with $10 \% \mathrm{FCS}$ for $60 \mathrm{~min}$ at $37^{\circ} \mathrm{C}$. PBMC stimulated in vitro with $10 \mu \mathrm{M}$ peptide and IL-2 $(1,000 \mathrm{IU} / \mathrm{ml})$ for 9 days were seeded in each well $\left(2 \times 10^{5} /\right.$ well $)$ in six replicates and stimulated with $10 \mu \mathrm{M}$ peptide. As positive control, an aliquot of the cells was stimulated with $1 \mu \mathrm{g} / \mathrm{ml}$ PMA (Sigma) and $0.25 \mu \mathrm{g} / \mathrm{ml}$ Ionomycin (Sigma). Plates were incubated for $18 \mathrm{~h}$ at $37^{\circ} \mathrm{C}$ in $5 \% \mathrm{CO}_{2}$, washed, and incubated with biotinylated anti-IFN- $\gamma$ detection $\mathrm{mAb}$ followed by alkaline phosphataseconjugated streptavidin. Spots were developed by adding peroxidase substrates (5-bromo-4,3-indolyl phosphate and nitroblue tetrazolium) and counted using the automated image analysis system Bioreader 2000 (BIOSYS, Karben, Germany).

\section{Results}

CT gene expression profile in patients with primary colon cancer

On the basis of a recent survey, it was found that most CT antigens that are encoded by genes located on chromosome $\mathrm{X}$ were rarely expressed in colon cancers whereas they were frequently expressed in metastatic melanomas [5, 16]. Because it is not known if the sporadic expression of CT antigens in CRC could nevertheless elicit antigen-specific $\mathrm{T}$ cell responses we screened a series of CRC patients for the expression of CT antigens. We focused our analysis on MAGE-A3, 
MAGE-A4, MAGE-A10, SSX2 and NY-ESO-1 because each contained at least one well-defined HLAA2-restricted T cell epitope.

Samples from 41 patients with primary CRC and 14 patients with metastatic liver lesions were collected. For 30 of the 41 patients, we obtained fresh tissue from the tumor and from the normal adjacent colonic mucosa. Moreover, for 6 of these patients, we were able to collect tissue both from the primary and hepatic metastatic tumors. The median age of the patients was 66 years, ranging from 43 to 91 years. None of them received chemotherapy or radiotherapy prior to surgery.

RNA was extracted from each individual sample and reverse-transcribed. The expression of CT genes was assessed by semi-quantitative PCR. cDNA from testis and the CT-gene positive melanoma cell line SK-MEL-37 were used as positive controls. Normal colon tissue was used as negative control. To evaluate the amount of RNA extracted from each sample, we performed quantitative PCR on $\beta$-actin (data not shown).

As shown in Table 1, the expression of the different CT genes in primary CRC varied between $2 \%$ for $M A G E-A 10$ and $15 \%$ for $M A G E-A 4$. The frequency of CRC patients expressing $M A G E-A 3$ was 13 and $4 \%$ for $N Y$-ESO- 1 and $S S X 2$. The majority of tumors did not express any $\mathrm{CT}$ gene, confirming the previous findings that colon cancer is a poor $\mathrm{CT}$ antigen expresser $[5,16]$. However, co-expression of several CT genes was observed in patients LAU846, LAU888 and LAU911 (Fig. 1). Contrary to bladder carcinoma [17], we did not detect any correlation between the neo-expression of the $\mathrm{CT}$ genes and
Table 1 CT gene expression frequencies in colon cancer primary tumors

\begin{tabular}{llll}
\hline Antigen & $n$ & Events & Frequency (\%) \\
\hline$M A G E-A 3$ & 45 & 6 & 13 \\
$M A G E-A 4$ & 48 & 7 & 15 \\
$M A G E-A 10$ & 48 & 1 & 2 \\
$N Y$ - $E S O-1$ & 48 & 2 & 4 \\
$S S X 2$ & 45 & 2 & 4 \\
\hline
\end{tabular}

tumor differentiation, although the number of positive tumors was probably too small to draw firm conclusions.

Comparison of the CT gene expression profile between primary and metastatic tumors

Previous reports suggested that, in melanoma, the frequency of expressed genes was increased during progression from primary to metastatic disease [18]. Thus, the low frequency of CT antigen expression in CRC could be due to the fact that, contrary to melanoma, the majority of CRC tumor specimens are isolated from primary lesions [5]. To test this hypothesis, we screened samples obtained from liver metastases of 14 CRC patients. Importantly, for six of those specimens, we also had access to the corresponding primary tumor, allowing a comparison of the expression pattern within the same patient. The results obtained in patient LAU846 (Fig. 1) are representative of what was observed with the samples of the other five patients. Overall, the expression of $M A G E-A 3,-A 4$ and $-A 10, N Y-E S O-1$ and $S S X 2$ was not more frequent in the hepatic metastatic lesions

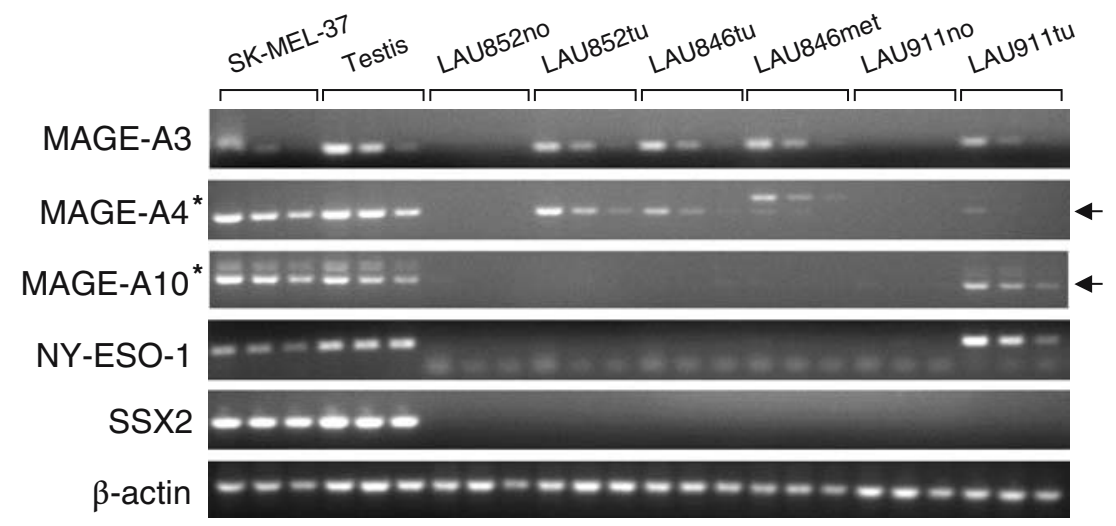

Fig. 1 Analysis of CT gene expression by semi-quantitative RTPCR. Expression of MAGE-A3, MAGE-A4, MAGE-A10, NYESO-1, SSX2 and the housekeeping gene $\beta$-actin in normal and tumor samples of LAU852 and LAU911 as well as tumor and metastatic samples of LAU846 was analyzed by RT-PCR. For each tissue sample, PCR was performed on serial fivefold dilutions of the cDNA. The cDNA prepared from human testis and the melanoma cell line SK-MEL-37 were used as positive controls. Arrows indicate the specific product and stars genomic contamination 
than in the primary tumors (Table 2). We therefore conclude that the low expression of CT gene in CRC cannot be ascribed to the stage of the tumor but rather reveal intrinsic differences between melanoma and CRC.

Immunohistochemical analysis of CT antigens in CRC lesions

For some of the patients that were found to express one or several CT genes by RT-PCR, we performed immunohistochemical analysis of their tumor specimens. Paraffin-embedded histological slides of tumor samples located next to the ones used for RT-PCR were stained with monoclonal antibodies raised against MAGE-A3 (clone 57B), MAGE-A1 (clone

Table 2 CT gene expression frequencies in colon cancer metastases

\begin{tabular}{lllc}
\hline Antigen & $n$ & Events & Frequency (\%) \\
\hline$M A G E-A 3$ & 12 & 1 & 8 \\
$M A G E-A 4$ & 14 & 2 & 14 \\
$M A G E-A 10$ & 14 & 0 & 0 \\
$N Y$ - $E S O-1$ & 10 & 1 & 10 \\
SS 2 & 10 & 0 & 0 \\
\hline
\end{tabular}

6C1) and NY-ESO-1 (clone D8.38). These antibodies have been extensively characterized earlier and crossreactivity of the two anti-MAGE-A clones against other members of the MAGE-A family has been described [13].

Patient LAU846, LAU852 and LAU911 were found to express MAGE-A3 and MAGE-A4 in their tumors by RT-PCR. Immunostaining of the primary tumor specimens of these patients with mAb 57B confirmed the expression of MAGE-A3 detected by PCR (Fig. 2). A strong staining was observed for MAGE-A3 in testicular seminoma, whereas the intensity of the staining was lower in CRC, suggesting that the antigen was expressed at low levels. Staining with mAb $6 \mathrm{C} 1$ showed similar results for patients LAU846 and 852. Expression appeared much stronger in the samples from patient LAU911, possibly due to the strong expression of MAGEA10, against which this mAb cross-reacts [13]. With both $\mathrm{mAb}$, the staining was heterogeneous in the carcinomatous glands and predominantly in the nucleus of the tumor cells. Positive NY-ESO-1 staining was also found for patient LAU911. This result is in agreement with the expression detected by RTPCR.

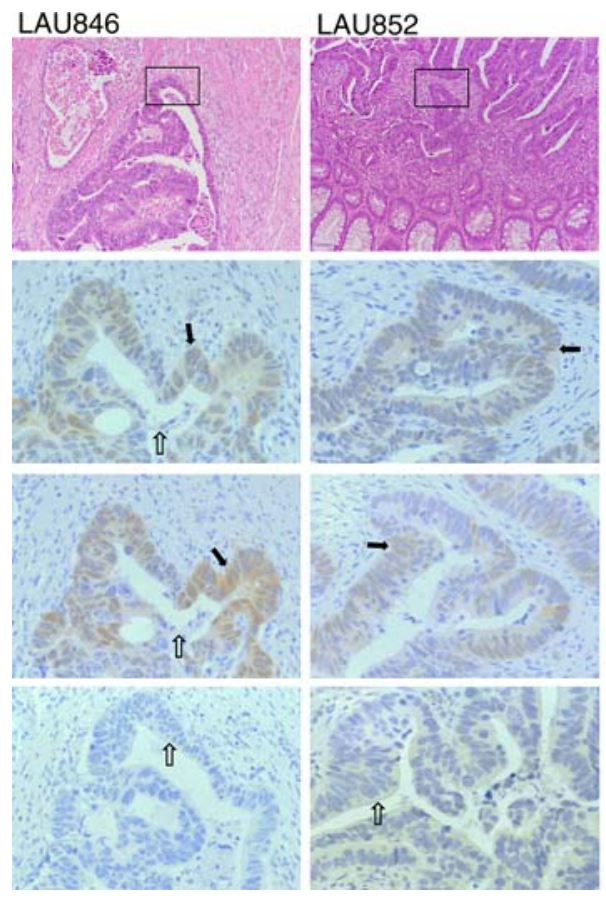

Fig. 2 Detection of CT antigen expression in CRC by immunohistochemistry. Sections of the primary CRC tumors isolated from the CT antigen-positive patients LAU846, LAU852 and LAU911 were stained with mAb anti-MAGE (57B and 6C1) and anti-NY-ESO-1 (D8.38). As positive control, sections from CT antigen-positive testicular seminoma were stained with the same

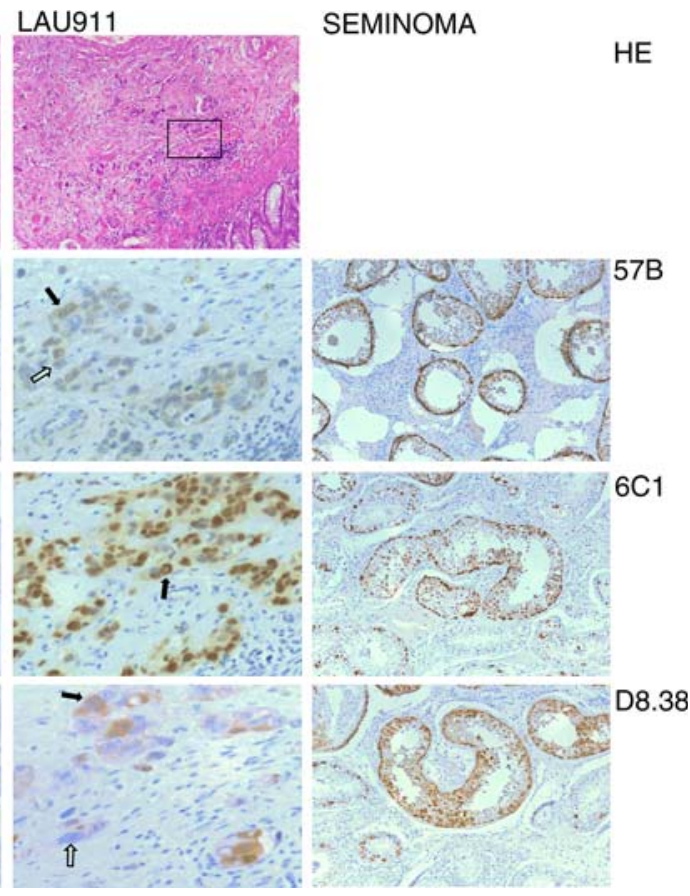

set of antibodies. Hematoxylin/eosin staining of the individual sections is shown at lower magnification. Filled arrows indicate an example of positive stained tumor cell. Empty arrows indicate an example of negative stained tumor cell. The region shown at higher magnification after mAb staining is boxed 


\section{Detection of $\mathrm{T}$ cell responses against $\mathrm{CT}$ antigens}

Having demonstrated expression of MAGE-A3, MAGE-A10 and NY-ESO-1 in patients LAU846 and LAU911, we determined if these patients displayed evidence of naturally developed $\mathrm{CD} 8^{+} \mathrm{T}$ cell responses against any of the three $\mathrm{CT}$ antigens. PBMC from patient LAU911 (HLA-A1, -A2, -B51, -B57) were stimulated once with the HLA-A2-restricted NY-ESO$1_{157-165}$ [19], MAGE-A $3_{112-120}$ [20] or MAGE-A10 ${ }_{254-262}$ peptides [21] and enumerated, after 10 days of culture, with HLA-A2 tetramers incorporating the corresponding peptides. As shown in Fig. 3a, $0.1 \%$ specific $\mathrm{CD}^{+} \mathrm{T}$ cells were detected by the $\mathrm{A} 2^{\mathrm{NY}-\mathrm{ESO}-1}$ tetramer in patient LAU911. MAGE-A $3_{112-120^{-}}$and MAGEA10 $254-262^{-r e a c t i v e ~} \mathrm{CD} 8^{+} \mathrm{T}$ cells remained undetectable in patients LAU919, LAU911, LAU942, LAU987 and LAU919, LAU911, respectively. As negative control, we performed the same experiment using PBL obtained from patient LAU919 (HLA-A2 ${ }^{+}$MAGEA3 ${ }^{-}$MAGE-A10 ${ }^{-}$NY-ESO-1 ${ }^{-}$) but we did not detect any tetramer staining.
Fig. 3 T cell responses in CT antigen-positive $\mathrm{CRC}$ patients. a Detection of CT antigen-specific T cells in HLAA2 patients by $\mathrm{A} 2$ tetramers. PBMC from patients LAU919 (MAGE-A3 ${ }^{-}$MAGE-A10 NY-ESO-1 ${ }^{-}$), LAU911 (MAGE-A3 $3^{+}$MAGE-A10 ${ }^{+}$ NY-ESO-1 $\left.{ }^{+}\right)$, LAU942 and $987\left(\mathrm{MAGE}^{-\mathrm{A}^{+}}{ }^{+}\right.$) were stimulated individually in vitro with peptides MAGE-A $3_{112-}$ 120, MAGE-A10 $10_{254-262}$ and NY-ESO-1 157-165 (LAU919 and LAU911) or only MAGE-A3 ${ }_{112-120}$ (LAU942 and LAU987). At day 10, peptide-specific $\mathrm{CD}^{+} \mathrm{T}$ cells were detected by flow cytometry with A2 tetramers incorporating the corresponding peptides. Dead cells were excluded by PI staining. b IFN- $\gamma$ ELISPOT assay of in vitro stimulated PBMC of patient LAU846. PBMC were stimulated once in vitro with peptides NY-ESO-1ORF2 $46-54$ and MAGEA $3_{167-176}$ and analyzed at day 10. Autologous cells were used as antigen-presenting cells in the presence of peptides. Quantification of spotforming $T$ cells was done after $16 \mathrm{~h}$ of incubation
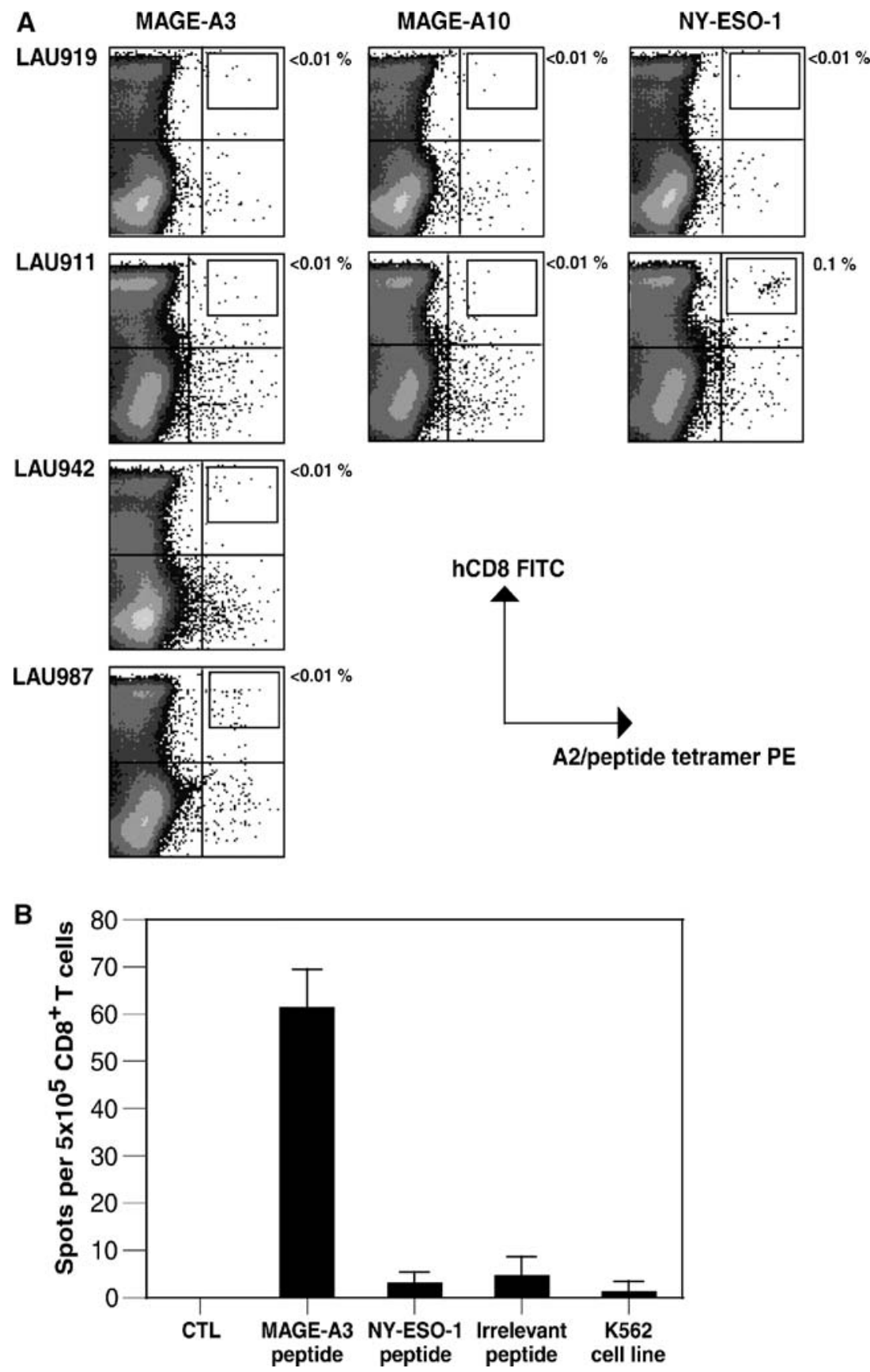
Peripheral blood mononuclear cell isolated from patient LAU846 (HLA-A*2501, -A29, -B*0705, -B18) were stimulated once in vitro with peptides derived from MAGE-A3 and NY-ESO-1. Because LAU846 was HLA-A2-negative, peptides NY-ESO-1-ORF2 ${ }_{46-54}$ and MAGE-A $3_{167-176}$ were selected. These two peptides were previously shown to be naturally processed and presented by HLA-B7 and HLA-B18, respectively $[22,23]$. Since B7 and B18 tetramers are not available, stimulated $\mathrm{T}$ cells were tested in IFN- $\gamma$ ELISPOT assays, using as targets, peptide-pulsed autologous cells. As shown in Fig. 3b, a significant proportion of T cells stimulated with MAGE-A3 ${ }_{167-176}$ released IFN- $\gamma$ upon incubation with peptide-pulsed target cells. In contrast, no response was detected after stimulation of $\mathrm{T}$ cells with NY-ESO-1-ORF2 ${ }_{46-54}$ or an irrelevant peptide. On the basis of this assay, the frequency of MAGE-A3-specific T cells was estimated to be approximately 1 in $10^{4} \mathrm{CD}^{+} \mathrm{T}$ cells.

\section{Discussion}

Our study shows that expression of CT genes, such as MAGE-A3, -A4, -A10, SSX2 and NY-ESO-1, is infrequent in human CRC. In spite of this fact, evidence of naturally acquired $\mathrm{T}$ cell responses could be demonstrated in some of the patients expressing one or the other CT antigens in their tumors.

A recent survey across various cancers revealed a large disparity in the frequencies of CT gene expression. While melanoma, non-small cell lung carcinoma, liver and bladder cancers frequently express products of the MAGE family or NY-ESO-1, CRC, leukemias and renal cancers rarely express these genes ([5] and references therein). Our results confirm these observations with respect to CRC. Interestingly, we found more frequent expression of $M A G E-A 3$ and $M A G E$ $A 4$ (13 and $15 \%$, respectively) than any of the other CT genes. A similar observation was also made by $\mathrm{Li}$ et al. [16], who analyzed more than 100 CRC tissues for the expression of CT genes. Despite this slightly more frequent expression of $M A G E-A 3$ and $-A 4$, most CRC lesions did not express any of the five CT genes tested here. A possibility for this infrequent CT gene expression in CRC could be due to the stage of the tumor at the time of resection. However, our analysis was performed on tumors of different TNM stages, ranging from stage I to stage IV, and, on the basis of our sampling, no correlation between the tumor stages and the profile of CT gene expression could be established. Moreover, no increased frequency of CT genes expression was found among the 14 patients' metastatic tumors. Taken together, our results indicate that CT gene neo-expression in CRC is unlikely to be caused by epigenetic alterations during cancer progression such as general demethylation [24, 25].

Immunohistochemical analyses of CT antigenpositive CRC samples revealed weak expression of MAGE-A in LAU846 and LAU852. By comparison, strong staining of MAGE-A was detected in testicular seminoma samples. This result suggests that the expression level of MAGE-A gene products in CRC is modest. However, it is possible that the weak staining might be caused by the fact that the affinity of $\mathrm{mAb}$ 57B and 6C1 against different members of the MAGEA family varies significantly [13]. Moreover, the pattern of expression of the antigens within the lesions was heterogeneous. While some tumor regions were heavily stained, other regions were stained less or not at all. This expression pattern is not unusual for CT antigens and underscores the value of immunohistochemical analyses as complement of the commonly used PCR analyses [26, 27]. Indeed, RT-PCR being generally performed on RNA extracted from heterogeneous tissue samples, detection of CT gene expression by PCR might be misleading as the particular CT antigen could be highly expressed in a small subset of cells or, inversely, expressed at low levels in the majority of cells. Such distinctions, which are all too often disregarded, are of critical importance for the development of $T$ cell vaccines against cancer.

Induction of spontaneous anti-tumor $\mathrm{T}$ cell responses has been documented for a small number of CT antigen-derived epitopes. Among those tested here, NY-ESO-1 has been shown to be highly immunogenic and to elicit spontaneous $\mathrm{T}$ cell responses in HLA-A $2^{+}$NY-ESO- $1^{+}$melanoma and breast cancer patients $[9,28]$. Despite the very limited number of NY-ESO- $1^{+}$HLA-A2 ${ }^{+}$CRC patients identified in our study, we nevertheless found a significant frequency of NY-ESO-1-specific T cells in the PBL of such patient. This result shows for the first time, to our knowledge, that the expression of NY-ESO-1 in CRC can induce a specific $\mathrm{CD}^{+} \mathrm{T}$ cell response. Unfortunately, further phenotypic analyses of the specific $\mathrm{T}$ cells could not be undertaken because the patient had chosen not to continue to participate in the study. Thus, no additional blood sample was obtained. T cell response elicited by peptide MAGE-A3 $3_{167-176}$ was analyzed in a second patient. Because of the HLA haplotype of this patient, we selected a recently defined MAGE-A3 epitope restricted by HLA-B18 [23]. HLA-B18 is expressed in approximately $11 \%$ of the Caucasian population [29]. In this case again, we could show that specific $\mathrm{T}$ cells could be stimulated by peptide MAGE-A $3_{167-176}$ to 
produce IFN- $\gamma$. The frequency of specific $\mathrm{T}$ cells remained low but suggested that appropriate vaccination strategies could be used to boost this response.

Taken together, our results indicate that CRC expressing CT antigens can elicit antigen-specific $\mathrm{T}$ cell responses, which could be boosted by active vaccination in a small subset of CRC patients. However, priority should be given to the search of frequently and highly expressed CRC-associated antigens.

Acknowledgments The authors thank the patients who generously consented to participate in this study, Ms. D. Minaidis for invaluable help with tissue sample collection, Dr. P. Guillaume and Dr. I. F. Luescher for providing HLA-A2/peptide tetramers and Dr. D. Rimoldi for advice. This work was supported in part by the National Center of Competence in Research (NCCR)Molecular Oncology, a research instrument of the Swiss National Foundation, and by grants from the Swiss National Foundation and the Cancer Research Institute, New York.

\section{References}

1. Pohl C, Hombach A, Kruis W (2000) Chronic inflammatory bowel disease and cancer. Hepatogastroenterology 47:57-70

2. Chiba T, Ohtani H, Mizoi T, Naito Y, Sato E, Nagura H, Ohuchi A, Ohuchi K, Shiiba K, Kurokawa Y, Satomi S (2004) Intraepithelial CD8 + T-cell-count becomes a prognostic factor after a longer follow-up period in human colorectal carcinoma: possible association with suppression of micrometastasis. Br J Cancer 91:1711-1717

3. Funada Y, Noguchi T, Kikuchi R, Takeno S, Uchida Y, Gabbert HE (2003) Prognostic significance of CD8 + T cell and macrophage peritumoral infiltration in colorectal cancer. Oncol Rep 10:309-313

4. Naito Y, Saito K, Shiiba K, Ohuchi A, Saigenji K, Nagura H, Ohtani H (1998) $\mathrm{CD}^{+} \mathrm{T}$ cells infiltrated within cancer cell nests as a prognostic factor in human colorectal cancer. Cancer Res 58:3491-3494

5. Scanlan MJ, Simpson AJ, Old LJ (2004) The cancer/testis genes: review, standardization, and commentary. Cancer Immun $4: 1$

6. Germeau C, Ma W, Schiavetti F, Lurquin C, Henry E, Vigneron N, Brasseur F, Lethe B, De Plaen E, Velu T, Boon T, Coulie PG (2005) High frequency of antitumor $T$ cells in the blood of melanoma patients before and after vaccination with tumor antigens. J Exp Med 201:241-248

7. Ayyoub M, Stevanovic S, Sahin U, Guillaume P, Servis C, Rimoldi D, Valmori D, Romero P, Cerottini J-C, Rammensee H-G, Pfreundschuh M, Speiser D, Lévy F (2002) Proteasome-assisted identification of a SSX-2 derived epitope recognized by tumor reactive cytolytic $\mathrm{T}$ lymphocytes infiltrating metastatic melanoma. J Immunol 168:1717-1722

8. Valmori D, Dutoit V, Rubio-Godoy V, Chambaz C, Liénard D, Guillaume P, Romero P, Cerottini J-C, Rimoldi D (2001) Frequent cytolytic T-cell responses to peptide MAGEA10254-262 in melanoma. Cancer Res 61:509-512

9. Valmori D, Dutoit V, Lienard D, Rimoldi D, Pittet MJ, Champagne P, Ellefsen K, Sahin U, Speiser D, Lejeune F, Cerottini J-C, Romero P (2000) Naturally occurring human lymphocyte antigen-A 2 restricted $\mathrm{CD} 8^{+} \mathrm{T}$-cell response to the cancer testis antigen NY-ESO-1 in melanoma patients. Cancer Res 60:4499-4506
10. Rimoldi D, Rubio-Godoy V, Dutoit V, Lienard D, Salvi S, Guillaume P, Speiser D, Stockert E, Spagnoli G, Servis C, Cerottini J-C, Lejeune F, Romero P, Valmori D (2000) Efficient simultaneous presentation of NY-ESO-1/LAGE-1 primary and nonprimary open reading frame-derived CTL epitopes in melanoma. J Immunol 165:7253-7261

11. Tureci O, Chen YT, Sahin U, Gure AO, Zwick C, Villena C, Tsang S, Seitz G, Old LJ, Pfreundschuh M (1998) Expression of SSX genes in human tumors. Int J Cancer 77:19-23

12. Patard JJ, Brasseur F, Gil-Diez S, Radvanyi F, Marchand M, Francois P, Abi-Aad A, Van Cangh P, Abbou CC, Chopin D et al (1995) Expression of MAGE genes in transitional-cell carcinomas of the urinary bladder. Int J Cancer 64:60-64

13. Rimoldi D, Salvi S, Schultz-Thater E, Spagnoli GC, Cerottini J-C (2000) Anti-MAGE-3 antibody 57b and anti-MAGE-1 antibody $6 \mathrm{C} 1$ can be used to study different proteins of the MAGE-A family. Int J Cancer 86:749-751

14. Schultz-Thater E, Noppen C, Gudat F, Dürmüller U, Zajac P, Kocher T, Heberer M, Spagnoli GC (2000) NY-ESO-1 tumour associated antigen is a cytoplasmic protein detectable by specific monoclonal antibodies in cell lines and clinical specimens. Brit J Cancer 83:204-208

15. Montes M, Rufer N, Appay V, Reynard S, Pittet MJ, Speiser DE, Guillaume P, Cerottini JC, Romero P, Leyvraz S (2005) Optimum in vitro expansion of human antigen-specific CD8 $\mathrm{T}$ cells for adoptive transfer therapy. Clin Exp Immunol 142:292-302

16. Li M, Yuan Y-H, Han Y, Liu Y-X, Yan L, Wang Y, Gu J (2005) Expression profile of cancer-testis genes in 121 human colorectal cancer tissue and adjacent normal tissue. Clin Cancer Res 11:1809-1814

17. Patard JJ, Brasseur F, Gil-Diez S, Radvanyi F, Marchand M, Francois P, Abi-Aad A, Van Cangh P, Abbou CC, Chopin D et al (1995) Expression of MAGE genes in transitional-cell carcinomas of the urinary bladder. Int J Cancer 64:60-64

18. Brasseur F, Rimoldi D, Lienard D, Lethe B, Carrel S, Arienti F, Suter L, Vanwijck R, Bourlond A, Humblet Y et al (1995) Expression of MAGE genes in primary and metastatic cutaneous melanoma. Int J Cancer 63:375-380

19. Jager E, Chen Y-T, Drijfhout JW, Karbach J, Ringhoffer M, Jager D, Arand M, Wada H, Noguchi Y, Stockert E, Old LJ, Knuth A (1998) Simultaneous humoral and cellular immune response against cancer-testis antigen NY-ESO-1: definition of human histocompatibility leukocyte antigen (HLA)-A2binding peptide epitopes. J Exp Med 187:265-270

20. Kawashima I, Hudson SJ, Tsai V, Southwood S, Takesako K, Appella E, Sette A, Celis E (1998) The multi-epitope approach for immunotherapy for cancer: identification of several CTL epitopes from various tumor-associated antigens expressed on solid epithelial tumors. Hum Immunol 59:1-14

21. Huang L-Q, Brasseur F, Serrano A, De Plaen E, van der Bruggen P, Boon T, Van Pel A (1999) Cytolytic T lymphocytes recognize an antigen encoded by MAGE-A10 on a human melanoma. J Immunol 162:6849-6854

22. Slager EH, van der Minne CE, Goudsmit J, van Oers JM, Kostense S, Havenga MJ, Osanto S, Griffioen M (2004) Induction of CAMEL/NY-ESO-ORF2-specific CD8 $+\mathrm{T}$ cells upon stimulation with dendritic cells infected with a modified Ad5 vector expressing a chimeric Ad5/35 fiber. Cancer Gene Ther 11:227-236

23. Bilsborough J, Panichelli C, Duffour MT, Warnier G, Lurquin C, Schultz ES, Thielemans K, Corthals J, Boon T, van der Bruggen P (2002) A MAGE-3 peptide presented by HLA-B44 is also recognized by cytolytic T lymphocytes on HLA-B18. Tissue Antigens 60:16-24 
24. Bariol C, Suter C, Cheong K, Ku SL, Meagher A, Hawkins N, Ward R (2003) The relationship between hypomethylation and $\mathrm{CpG}$ island methylation in colorectal neoplasia. Am J Pathol 162:1361-1371

25. Goelz SE, Vogelstein B, Hamilton SR, Feinberg AP (1985) Hypomethylation of DNA from benign and malignant human colon neoplasms. Science 228:187-190

26. Simpson AJ, Caballero OL, Jungbluth A, Chen YT, Old LJ (2005) Cancer/testis antigens, gametogenesis and cancer. Nat Rev Cancer 5:615-625

27. Jungbluth AA, Stockert E, Chen YT, Kolb D, Iversen K, Coplan K, Williamson B, Altorki N, Busam KJ, Old LJ (2000)
Monoclonal antibody MA454 reveals a heterogeneous expression pattern of MAGE-1 antigen in formalin-fixed paraffin embedded lung tumours. Br J Cancer 83:493-497

28. Jager E, Nagata Y, Gnjatic S, Wada H, Stockert E, Karbach J, Dunbar PR, Lee SY, Jungbluth A, Jager D, Arand M, Ritter G, Cerundolo V, Dupont B, Chen Y-T, Old LJ, Knuth A (2000) Monitoring CD8 T cell responses to NY-ESO-1: Correlation of humoral and cellular immune responses. Proc Natl Acad Sci USA 97:4760-4765

29. Eichler H, Richter E, Schwartz K, Woelpel A, Goldmann SF (1998) Caucasian German normal. In: Gjertson DW, Terasaki PI (eds) HLA, pp 150-151 